\title{
Online Courses and Online Teaching Strategies in Higher Education
}

\author{
Abigail Mitchell \\ School of Nursing, D'Youville College, Buffalo, USA \\ Email: mitchela@dyc.edu
}

Received 15 September 2014; revised 13 October 2014; accepted 15 November 2014

Copyright ( 2014 by author and Scientific Research Publishing Inc.

This work is licensed under the Creative Commons Attribution International License (CC BY). http://creativecommons.org/licenses/by/4.0/

(c) (i) Open Access

\begin{abstract}
Online faculty need to engage the student. Online course work is now an integral element of mainstream higher education. Online courses often lack face-to-face interaction, peer interaction, faculty feedback and the lack of community. Engagement of the learner is essential for learning and promoting student satisfaction. There are online teaching strategies that could enhance a student's perception of engagement. This manuscript was completed by a literature review process.
\end{abstract}

\section{Keywords}

Distance Learning, Online, Engagement, Nursing Education, Teaching Strategies

\section{Introduction}

In 1974, Regents External Degree was the first online program that was created in 1974, and many educators believed that distance-learning model was inappropriate for nursing education (Bastable, 2014). Distance learning (DL) has been utilized since the early 1990s, especially with the development of the Internet. In 2002, 1.6 million students took courses on-line across the United States. In 2003, the number of online course students rose to 1.97 million, succeeded by 2.33 in 2004, and in 2011 it was found that a third of all the students enrolled in postsecondary education had taken an accredited online course (Lederman, 2013). Online course work is now an integral element of mainstream higher education. About $63 \%$ of schools that offer undergraduate traditional classes also offer programs online (Olmstead, 2010). Nursing schools have also adapted to this mode of course delivery. According to American Association of College of Nursing (AACN, 2008), there is a current shortage of qualified nursing faculty and the number is expected to grow within the next decade. Online programs have allowed colleges to offer courses needed; however, schools still need qualified online faculty that can engage the student that will improve retention, satisfaction, and student outcomes. The research is a literature review. 


\section{Literature Review}

The goal of this review was to explore distance learning and teaching strategies that could enhance a nursing students learning outcome. According to the results of a survey of more than 2500 higher education institutions in the United States, approximately one third of institutions with health profession and related higher education programs offer online courses in these disciplines (Allen \& Seaman, 2008). Anxiety and isolation can be part of online learning, as well as feelings of confidence, encouragement, and mastery (Reilly, Lepak, \& Killion, 2009). Online courses often lack face-to-face interaction, peer interaction, faculty feedback, and the sense of not belonging. Many institutions view online instruction as a viable method to provide quality instruction at a reduced cost (Garbett, 2011). The results of a study of Washington State Community College showed that distance learning students tended to drop out more often than their traditional students due to difficulties in language, time management, and study skills (Stephens, 2007). Students often register for online courses without the proper tools or knowledge to participate in distance learning. It is suggested throughout the literature that students have access to an online orientation to familiarize themselves with online course features and working with various document files (Schrum, Burbank, Engle, Chambers, \& Glassett, 2005). The sense of belonging to an online community has been shown to be beneficial to student engagement, persistence, course satisfaction, and perhaps even perceived learning in online courses (Liu, Magiuka, Bonk, \& Lee, 2007). Engagement of the learner is essential for learning and promoting well-being. A student should feel connected to the college, faculty, and other students even if they are not actually sitting in a traditional classroom. The other avenue to explore was the theory that any nursing professor can teach online. This is not the case. Most instructors new to online teaching begin with little to no training or preparation specific to this delivery mode (Fish \& Wickersham, 2009). Nurse educators must be prepared to use technology in their classrooms and prepare to educate via online mode. Often it is more difficult for the instructor to organize and plan a distance-learning program, especially since many are new programs and their organizational needs are different from a traditional learning program (Stanton, 2001). Often students are able to learn in ways that traditional classrooms would not be able to provide. When course design and the learning environment are at their optimal conditions, distance learning can lead students to higher satisfaction with their learning experiences and produce solid student outcomes (Kirtman, 2009). Evidence shows that instructors need to maintain substantial involvement in online courses (Reushle \& Mitchell, 2009) to engage the student.

\section{Online Teaching Strategies}

Educator's role is to facilitate online discussions and providing structure. Learning outcomes for the student is essential. There are online teaching strategies that could enhance a student's perception of engagement, increase retention, and satisfaction.

- Open the course at least one week prior to traditional classes starting.

- Post a brief introduction of yourself, with a current picture.

- Provide links.

- Discussions should be weekly, informal or formal.

- Use rubrics for grading online discussions and assignments.

- Provide syllabus, course schedule, and your expectations of the student.

- Online office hours.

- Provide the student with campus office hours and your email.

The above strategies is found in many different articles, however the above is also based on this educator's personal experience with the peer review process for online courses. By opening the course at least one week prior to regular classes starting, allows the student ample time to review the setup of the online course. The course needs to be complete with a course syllabus, schedule with assignment due dates, and a grading rubric. If learners have positive perceptions of their interactions with the technological tools of the learning environment, it is likely that they will also have positive perceptions of their interactions with faculty and other learners (Arbaugh \& Rau, 2007). By posting a brief introduction of yourself, just like what you would state in your classroom and a picture(s) will also provide the student with a visual connection. Encourage the students to post their picture in the discussion forum. Pictures allow the student to have "face-to-face" interaction and promote the sense of community. Students should also introduce themselves and post a peer response. Include links that you will be referring to such as library, research, journals, and even videos. The book for the course can also be 
linked to the college bookstore, with a picture. Discussions should be weekly or chat rooms with peer posts that allow faculty feedback to promote the community and to facilitate learning. Using online office hours, posting traditional office hours, and contact information such as email, telephone number or even Skype information will enhance the student's learning perceptive. Faculty should also be complainant with American Disabilities Act (ADA) by using voice over power points to engage the hearing-impaired student.

\section{Conclusion}

The roles instructors play in facilitating productive online discussions can include managerial, social, pedagogical, and technical (Reushle \& Mitchell, 2009). Educating our students via online format is expected in many colleges today. Educators need to take the time to develop courses that utilize the most current technology that enhances the students learning. By following teaching strategies, this will enhance the online learning environment and provide student engagement, retention, and satisfaction will increase.

\section{Acknowledgements}

A thank you to Donna Simele for her online wisdom at Niagara County Community College.

\section{References}

Allen, E., \& Seamen, J. (2008). Staying the Course; Online Education in the United States.

American Association of Colleges of Nursing (AACN) (2008). Nursing Shortage. Fact Sheet.

Arbaugh, J. B., \& Rau, B. (2007). A Study Disciplinary, Structural, and Behavioral Effect on Course Outcomes in Online MBA Courses. Decision Sciences Journal of Innovative Education, 5, 65-93. http://dx.doi.org/10.1111/j.1540-4609.2007.00128.x

Bastable, S. (2014). Nurse as Educator (4th ed.). Jones and Barlett, Burlington.

Fish, W. W., \& Wickersham, L. E. (2009). Best Practices for Online Instructors; Reminders. Quarterly Review of Distance Education, 10, 279-284.

Garbett, C. (2011). Activity-Based Costing Models for Alternative Modes of Delivering Online Courses. European Journal of Open, Distance, and E-Learning, 1, 1-14.

Kirtman, L. (2009). Online versus In-Class Courses: An Examination of Differences in Learning Outcomes. Issues in Teacher Education, 18, 103-115.

Lederman, D. (2013). Growth for Online Learning. http://www.insidehighered.com

Liu, X. J., Magjuka, R. J., Bonk, C. J., \& Lee, S.-H. (2007). Does Sense of Community Matter. An Examination of Participants Perceptions of Building Learning Communities in Online Courses. Quarterly Review of Distance Learning, 8, 9-24.

Olmstead, J. (2010). An Analysis of Student Performance Benchmarks in Dental Hygiene via Distance Education. The Journal of Dental Hygiene, 84, 75-80.

Reilly, S., Lepak-Gallagher, S., \& Killion, C. (2009). Emotional Factors in Online Learning. Nursing Education Perspectives, 33, 100-104. http://dx.doi.org/10.5480/1536-5026-33.2.100

Reushle, S., \& Mitchell, M. (2009). Sharing the Journey of Facilitator and Learner: Online Pedagogy in Practice. Journal of Learning Design, 3, 11-20.

Schrum, L., Burbank, M., Engle, J., Chambers, J., \& Glassett, K. (2005). Post Secondary Educators Professional Development; Investigation of an Online Approach to Enhancing Teaching and Learning. Internet and Higher Education, 2, 279289. http://dx.doi.org/10.1016/j.iheduc.2005.08.001

Stanton, S. (2001). Going the Distance; Developing Shared Web-Based Learning Programmes. Occupational Therapy International, 8, 96-106. http://dx.doi.org/10.1002/oti.136

Stephens, D. (2007). Quality Issues in Distance Learning Education. 
Scientific Research Publishing (SCIRP) is one of the largest Open Access journal publishers. It is currently publishing more than 200 open access, online, peer-reviewed journals covering a wide range of academic disciplines. SCIRP serves the worldwide academic communities and contributes to the progress and application of science with its publication.

Other selected journals from SCIRP are listed as below. Submit your manuscript to us via either submit@scirp.org or Online Submission Portal.
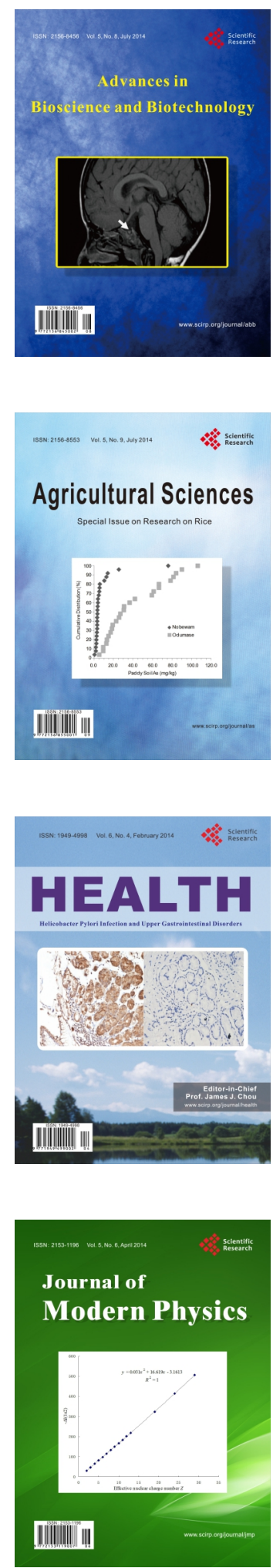
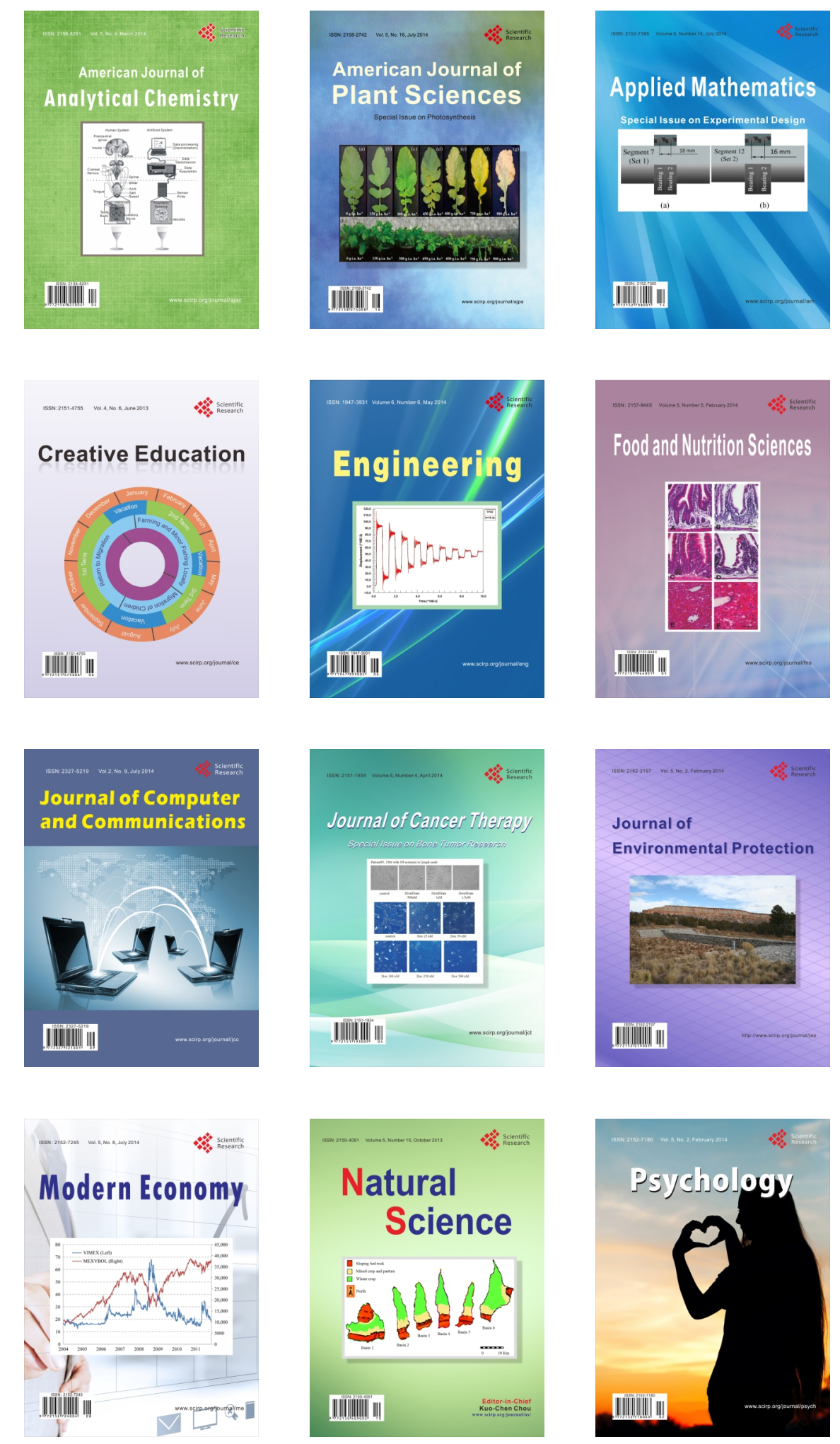